\title{
Waterlogging, Salinity and Combined Stress a Major Problem in Pigeonpea (Cajanus cajans L. Mill sp.)
}

\author{
Savita Duhan*, Sunita Sheokand and Anita Kumari
}

Dept. of Botany \& Plant Physiology CCS HAU, Hisar, Haryana (125 004), India

\section{Corresponding Author}

Savita Duhan

e-mail: savitaduhan53@gmail.com

\author{
Article History \\ Manuscript No. AR1797d \\ Received in $14^{\text {th }}$ February, 2017 \\ Received in revised form $18^{\text {th }}$ March, 2017 \\ Accepted in final form $6^{\text {th }}$ April, 2017
}

\begin{abstract}
The present investigation was conducted in Department of Botany and Plant Physiology, CCS Haryana Agricultural University, Hisar during 2014-15 and 2015-16. Waterlogging and salinity are most severe stress all around the world. When water and salt is present in excess amount than its optimum requirement it refers to waterlogging and salinity respectively. Waterlogging when combined with salinity exaberate the effect of salinity. Four pigeonpea genotypes (ICPH-2431, PARAS, UPAS-120, H09-33) were raised in polythene bags filled with half kg soil+FYM manure mixture and Carbohydrate metabolism and aerenchyma formation under twelve days waterlogging, salinity and combined stress was studied in roots of 20 and 40 day old pigeonpea plants 1,4 and 8 days after removal from treatment under pot house conditions. Decline in total and nonreducing sugar content and a significant increase in reducing sugar content, sucrose synthase activity and alcohol dehydrogenase activity was observed with waterlogging and salinity stress. No survival was observed under combined waterlogging and salinity treatment in any genotypes. Waterlogging was found more deleterious compared to alone salinity treatment. Aerenchyma formation was observed only under waterlogging treatment. Both the stresses are found more deleterious when given at later stages of growth. ICPH performed best among all the genotypes followed by PARAS, HO9-33 and UPAS-120 in terms of total sugar, nonreducing sugar, reducing sugar, sucrose synthase activity, alcohol dehydrogenase activity and aerenchyma formation.
\end{abstract}

Keywords: Aerenchyma, carbohydrate metabolism

\section{Introduction}

Abiotic stresses like waterlogging and salinity affects large area of world (Zeng et al., 2013; CSSRI, 2016). Both of these stresses affect growth of plant by affecting a number of physiological processes like photosynthesis, water uptake and respiration etc (Bajpai and Chandra, 2015). Increased level of water decreases the availability of oxygen to plant by creating hypoxic condition and finally leads to death of plant due to anoxia (complete absence of oxygen) (Ashraf, 2012; Akhtar and Nazir, 2013). Since oxygen is a terminal acceptor in aerobic respiration its absence blocks the kreb cycle and electron transport chain. However plant uses several strategies to cope up with stresses like anerobic respiration to produce adenosine triphosphate (ATP) and aerenchyma formation (Hossain and Uddin, 2011; Kulkarni and Chavan, 2013). Similarly salinity stress also affects the water relation of the plant. Initially plant faces water scarcity which in turn reduces leaf expansion but later when this water scarcity is prolonged it results into decreased photosynthesis and sucrose phosphate synthase activity which converts hexose phosphates into sucrose (Amirjani, 2010). Plants also have some mechanism like accumulation of proline, soluble sugar, glycine betain and sugar alcohols to cope up with salinity stress (Celik and Atak, 2012). Pigeonpea (Cajanus cajan (L.) Millsp.) is the sixth most important grain legume of tropics and subtropics. Because of its multiple uses, it plays an important role in subsistence agriculture. In India, pigeonpea is mainly grown in the regions lying between $14^{\circ} \mathrm{N}$ and $29^{\circ} \mathrm{N}$ latitudes with mean annual rainfall ranging between 600 and $1500 \mathrm{~mm}$. Majority of these areas are endowed with a dependable and high rainfall pattern. Waterlogging is a perennial production problem in these areas which are characterized with alluvial or deep vertisols (Bansal and Srivastava, 2012). Salinity is an ever-increasing abiotic stress affecting about 95 mha or around $20 \%$ of land worldwide (Aksoy and Dinler, 2014). These environmental stress significantly contribute in reduction of crop yield (Basiri et al., 2013; Javed et al., 2014). So, soil salinity can be a major constraint to pigeonpea in regions where it is predominantly grown (Choudhary et al., 2011).

The combined effects of salinity and waterlogging are common in saline areas, particularly where shallow salinewater tables exist or where soils are also sodic, reducing 
water infiltration and causing water to pond on the soil surface (Barrett-Lennard, 2003). For many plant species, when salinity and waterlogging occur together, a large increase in $\mathrm{Na}^{+}$and $\mathrm{Cl}^{-}$concentrations in shoots occurs due to increased entry of these ions into oxygen deficient roots (Barrett-Lennard, 2003). Thus, waterlogging can exacerbate the effects of salinity (e.g. aize, (Drew et al., 1988). Therefore, the present work was conducted to study the independent and interactive effects of twelve days waterlogging and salinity on carbohydrate metabolism and aerenchyma formation in pigeonpea genotypes.

\section{Materials and Methods}

Four genotypes were raised in polythene bags filled with half kg soil+FYM manure mixture (3 soil: 1manure v/v), NPK (@ 20:60:20 kg ha-1). Twenty and forty days after sowing the pots were placed in cemented tanks (length 160 $\mathrm{cm}$, breadth $125 \mathrm{~cm}$ and depth $65 \mathrm{~cm}$ ). Three treatments i.e. alone waterlogging, alone salinity $(30 \mathrm{mM} \mathrm{NaCl})$ and waterlogging+salinity $(30 \mathrm{mM} \mathrm{NaCl})$ in combination were given for 12 days. Under waterlogging and combined treatment of waterlogging and salinity, plants with polythene bags were put in cemented tanks filled with simple water and $30 \mathrm{mM} \mathrm{NaCl}$ solution respectively. Solutions were drained out 12 days after treatment and observations were recorded 1, 4 and 8 days after removal from treatment in the roots of plants. Alone salinity $(30 \mathrm{mM} \mathrm{NaCl}$ ) treatment was given by only irrigating plants with $30 \mathrm{mM} \mathrm{NaCl}$ solution instead of water time to time. Under waterlogging treatment, plants were waterlogged with pure water and under waterlogging+salinity treatment plants were waterlogged in saline solution. In case of alone salinity treatment only time to time irrigation was given saline solution and no waterlogged condition was created in alone salinity treatment Statistical design was two factorial randomized design (4 Replications)

\subsection{Survival percentage was calculated after the living plants}

were counted and expressed in the term of percent survival. Total soluble sugar content was estimated using method prescribed by Yemm and Willis (1954), reducing sugar content by DNS method (Miller, 1959). Non-reducing sugar content was measured by deducing reducing sugar content from the total sugar content.

\subsection{Sucrose synthase}

Extraction buffer consisted of 200 mM HEPES containing+1 Mm DTT+5 mM magnesium chloride+1 mM EDTA+20 $\mathrm{mM}$ sodium ascorbate+1 mM PMSF+10\% (w/v) polyvinyl polypyrrolidone, and $\mathrm{pH}$ was adjusted to 7.5. One gram of plant material was ground followed by extraction with chilled extraction buffer $(10 \mathrm{ml})$. Extract was centrifuged at $14,000 \mathrm{rpm}$ at $4{ }^{\circ} \mathrm{C}$ for $10 \mathrm{~min}$. Supernatant was dialyzed at 4 ${ }^{\circ} \mathrm{C}$ for $24 \mathrm{~h}$ against extraction buffer diluted 1:40, which was changed at least three times during dialysis. The reaction mixture contained 50 mM HEPES-NaOH buffer ( $\mathrm{pH} 7.5), 15$
$\mathrm{mM}$ magnesium chloride, $10 \mathrm{mM}$ fructose, $5 \mathrm{mM}$ UDP-glucose, $50 \mathrm{ml}$ enzyme extract and water to make final volume $3.0 \mathrm{ml}$. Assay was conducted at $30^{\circ} \mathrm{C}$ for $30 \mathrm{~min}$ in a shaking water bath incubator, and reaction was terminated by addition of $1 \mathrm{ml}$ of $30 \% \mathrm{KOH}$. Controls were terminated at $0 \mathrm{~min}$. The unreacted fructose was removed by subsequent heating at $100{ }^{\circ} \mathrm{C}$ for $10 \mathrm{~min}$. After cooling, each assay mixture was incubated with $1 \mathrm{ml}$ of $0.14 \%$ anthrone in $\mathrm{H}_{2} \mathrm{SO}_{4}$ at $40{ }^{\circ} \mathrm{C}$ for $20 \mathrm{~min}$ and absorbance recorded at $620 \mathrm{~nm}$.

\subsection{Alcohol dehydrogenase}

The extraction buffer consisted of $50 \mathrm{mM}$ Tris- $\mathrm{HCl}+15 \mathrm{mM}$ DTT, pH 8.0. Plant tissue of $0.5 \mathrm{~g}$ was homogenized with 5.0 $\mathrm{ml}$ of extraction buffer. The extract was centrifuged at 12,000 rpm for $15 \mathrm{~min}$ at $4{ }^{\circ} \mathrm{C}$. The $3 \mathrm{ml}$ reaction mixture contained 50 mM Tris buffer, 0.867 mM NAD, 20\% ethanol, $50 \mathrm{ml}$ enzyme extract and double distilled water. Reaction mixtures except NAD were prepared in test tubes, and each sample used as blank to adjust zero. NAD was added to initiate the reaction and increase in absorbance due to $\mathrm{NADH}$ at $340 \mathrm{~nm}$ recorded for $1 \mathrm{~min}$. Amount of NADH formed is computed by drawing a standard curve of NADH at $340 \mathrm{~nm}$ and activity is expressed as nmol NADH formed per mg protein per minute.

\subsection{Aerenchyma formation in roots}

Root was sampled below the root-shoot transition region. The materials were fixed in formalin-acetic acid-alcohol solution FAA (Sass, 1964) at vegetative stage one day after removal of eight treatments. After 24-48 hrs, the materials were washed and preserved in $70 \%$ alcohol till further use. The preserved materials when used were dehydrated through ethanol xylene series and then infiltrated and embedded in paraffin wax (congealing point $58-60{ }^{\circ} \mathrm{C}$ ). Serial transverse sections of roots were cut at $8-10 \mu \mathrm{m}$ on rotary microtome Johansen, 1940 (Spencer 820 microtome, USA). Affixing of the paraffin ribbons to the slides was made by using synthetic gum. Conventional combination like safranin and light green stain (Johansen, 1940) were used for studying the aerenchyma formation in roots.

\section{Results and Discussion}

\subsection{Percent survival}

Twelve days $\mathrm{W}$ treatment resulted in 50-75\% decrease in percent survival 1 DAR which further increased to 65-90\% and $100 \% 4$ and 8 DAR respectively in 20 day old plants (Table 1 ). Salinity treatment alone had no deleterious effect and no decline in percent survival was observed. Waterlogging and salinity treatment in combination was more deleterious resulting in $100 \% 1,4$ and 8 DAR from 12 days treatment. Forty day old plants recorded no survival with 12 days $W$ and $W+S$ treatment 1, 4 and 8 DAR. No decline in percent survival was observed under $\mathrm{S}$ treatment also in 40 day old plants. ICPH 2431 performed best under $\mathrm{W}$ and $\mathrm{W}+\mathrm{S}$ treatments ( 8 days and 12 days) followed by PARAS, HO9-33 and UPAS-120 in 20 day as well as 40 day old plants. 


\begin{tabular}{|c|c|c|c|c|c|c|c|c|c|c|c|c|c|c|c|c|c|c|c|c|c|c|}
\hline \multirow{3}{*}{$\begin{array}{l}\text { Gen- } \\
\text { otype }\end{array}$} & \multicolumn{11}{|c|}{20 DAS } & \multicolumn{11}{|c|}{40 DAS } \\
\hline & \multicolumn{4}{|c|}{12 day $^{*}(1 \text { day })^{* *}$} & \multicolumn{4}{|c|}{$12 \operatorname{day}^{*}(4 \text { day })^{* *}$} & \multicolumn{3}{|c|}{$\begin{array}{c}12 \text { day }^{*} \text { (ay) } \\
\text { (a* }\end{array}$} & \multicolumn{4}{|c|}{$12 \operatorname{day}^{*}(1 \text { day })^{* *}$} & \multicolumn{4}{|c|}{$12 \operatorname{day}^{*}(4 \text { day) })^{* *}$} & \multicolumn{3}{|c|}{$\begin{array}{c}12 \text { day }^{*}(8 \\
\text { day) }\end{array}$} \\
\hline & C & W & $S$ & $\begin{array}{l}\text { W+ } \\
\mathrm{S}^{\#}\end{array}$ & C & W & $S$ & $\begin{array}{l}\mathrm{W}+ \\
\mathrm{S}^{\#}\end{array}$ & W\# & $S$ & $\begin{array}{c}\mathrm{W+} \\
\mathrm{S}^{\#}\end{array}$ & C & $W^{\#}$ & $S$ & $\begin{array}{l}\mathrm{W}+ \\
\mathrm{S}^{\#}\end{array}$ & C & $W^{\#}$ & $S$ & $\begin{array}{c}\text { W+ } \\
S^{\#}\end{array}$ & $\mathrm{~W}^{\#}$ & $S$ & $\begin{array}{l}\mathrm{W}+ \\
\mathrm{S}^{\#}\end{array}$ \\
\hline $\begin{array}{l}\text { ICPH } \\
2431\end{array}$ & 100 & 50 & 100 & 0 & 100 & 38 & 100 & 0 & 0 & 100 & 0 & 100 & 0 & 100 & 0 & 100 & 0 & 100 & 0 & 0 & 100 & 0 \\
\hline $\begin{array}{l}\text { UPAS } \\
120\end{array}$ & 100 & 24 & 100 & 0 & 100 & 15 & 100 & 0 & 0 & 100 & 0 & 100 & 0 & 100 & 0 & 100 & 0 & 100 & 0 & 0 & 100 & 0 \\
\hline $\begin{array}{l}\mathrm{HO9} \\
33\end{array}$ & 100 & 41 & 100 & 0 & 100 & 21 & 100 & 0 & 0 & 100 & 0 & 100 & 0 & 100 & 0 & 100 & 0 & 100 & 0 & 0 & 100 & 0 \\
\hline $\begin{array}{l}\text { PA- } \\
\text { RAS }\end{array}$ & 100 & 43 & 100 & 0 & 100 & 26 & 100 & 0 & 0 & 100 & 0 & 100 & 0 & 100 & 0 & 100 & 0 & 100 & 0 & 0 & 100 & 0 \\
\hline
\end{tabular}

"Duration of treatment; ${ }^{* *}$ stage of sampling; \# no survival was observed

\subsection{Carbohydrate metabolism}

\subsubsection{Total soluble sugar content}

A decline of $14-26 \%$ and $7-14 \%$ was observed in total sugar content of 20 day old plant roots 1 DAR from 12 days $W$ and $S$ treatment which further decreased to 5-7\% and 3-7\% 4 DAR in case of 12 days $\mathrm{W}$ and S treatment respectively (Table 2).
Salinity treatment also resulted 3 to $7 \%$ increase 8 DAR from 12 days treatment. Waterlogging+Salinity was found more deleterious to all genotypes and resulted in no survival. Forty day old plant roots showed more decline in comparison to 20 days plant roots. A decline of 11 to $22 \% 1$ DAR from 12 days $S$ treatment was observed. Salinity (12 days) treatment resulted in 2 to $5 \%$ decline 4 DAR from treatment. The decline was 6

Table 2: Effect of waterlogging, salinity and their combination (12 days) on total sugar content (mg $\mathrm{g}^{-1} \mathrm{dry}$ weight) in pigeonpea roots

\begin{tabular}{|c|c|c|c|c|c|c|c|c|c|c|c|c|c|}
\hline \multirow[t]{3}{*}{ Genotype } & \multicolumn{10}{|c|}{20 DAS } & \multicolumn{3}{|c|}{40 DAS } \\
\hline & \multicolumn{4}{|c|}{12 day $^{*}\left(1\right.$ day) ${ }^{* *}$} & \multicolumn{4}{|c|}{12 day $^{*}\left(4\right.$ day) ${ }^{* *}$} & \multicolumn{2}{|c|}{12 day $^{*}\left(8\right.$ day) ${ }^{* *}$} & \multicolumn{3}{|c|}{12 day $^{*}\left(1\right.$ day) ${ }^{* *}$} \\
\hline & $\mathrm{C}$ & W & $\mathrm{S}$ & Mean" & C & W & $\mathrm{S}$ & Mean & $\mathrm{S}$ & Mean\# & C & $\mathrm{S}$ & Mean\# \\
\hline ICPH 2431 & 24.3 & 20.9 & 22.6 & 22.6 & 24.8 & 23.5 & 27 & 24.9 & 24.1 & 24.5 & 25.1 & 22.3 & 23.7 \\
\hline UPAS 120 & 23.6 & 17.4 & 20.4 & 20.5 & 23.8 & 22.1 & 24 & 23.4 & 22.2 & 23 & 24.2 & 18.9 & 21.6 \\
\hline HO9 33 & 23.9 & 18.4 & 20.9 & 21.1 & 24.1 & 22.7 & 25 & 24 & 22.6 & 23.4 & 24.4 & 19.6 & 22 \\
\hline PARAS & 24.1 & 19.9 & 22.1 & 22 & 24.4 & 23.2 & 26 & 24.5 & 23.5 & 24 & 24.7 & 21.8 & 23.3 \\
\hline Mean & 24 & 19.2 & 21.5 & & 24.3 & 22.9 & 26 & & 23.1 & & 24.6 & 20.7 & \\
\hline $\operatorname{CD}(p=0.05)$ & \multicolumn{4}{|c|}{$\mathrm{T}-0.41, \mathrm{G}-0.48, \mathrm{~T} \times \mathrm{G}-0.82$} & \multicolumn{4}{|c|}{ T-0.24, G-0.27, T×G-0.47 } & T-0.42, & 9, T×G-N.S. & \multicolumn{3}{|c|}{ T-0.54, G-0.76, T×G-1.08 } \\
\hline
\end{tabular}

Table 2: Continue...

\begin{tabular}{|c|c|c|c|c|c|}
\hline \multirow[t]{3}{*}{ Genotype } & \multicolumn{5}{|c|}{40 DAS } \\
\hline & \multicolumn{3}{|c|}{12 day $^{*}(4 \text { day) })^{* *}$} & \multicolumn{2}{|c|}{12 day $^{*}(8 \text { day })^{* *}$} \\
\hline & $\mathrm{C}$ & $\mathrm{S}$ & Mean & S & Mean" \\
\hline ICPH 2431 & 25.3 & 24.8 & 25.1 & 23.9 & 24.6 \\
\hline UPAS 120 & 24.3 & 23.2 & 23.8 & 21.7 & 23 \\
\hline HO9 33 & 24.5 & 23.5 & 24 & 22.1 & 23.3 \\
\hline PARAS & 24.9 & 24.5 & 24.7 & 23.1 & 24 \\
\hline Mean & 24.8 & 24 & & 22.7 & \\
\hline $\begin{array}{l}C D \\
(p=0.05)\end{array}$ & \multicolumn{3}{|c|}{$\begin{array}{c}\text { T-0.60, G-0.85, } \\
\text { T×G N.S. }\end{array}$} & \multicolumn{2}{|c|}{$\begin{array}{c}\text { T-0.48, G-0.68, } \\
\text { T×G- N.S. }\end{array}$} \\
\hline
\end{tabular}

to $11 \% 8$ DAR from 12 days $S$ treatment. No plant survived 4 DAR from 12 days combined treatment, 8 DAR from 12 days waterlogging and 1 and 8 DAR from 12 days combined treatment in 20 day old pigeonpea plants and 4 DAR from 12 days and 1 and 8 DAR from 12 days waterlogging and waterlogging+salinity treatment in 40 day old pigeonpea plants. ICPH 2431 performed best among the genotypes under all treatments. Sairam et al. (2009b) also noticed that during waterlogging roots of comparatively tolerant genotypes showed greater sugar content than susceptible one in pigeonpea. Horchani et al. (2010) also investigated the interactive effects of salinity and hypoxia on the physiological responses of tomato (Solanum lycopersicum L.) plants and 
reported an increase in root carbohydrate content and a decrease in leaf carbohydrate content. Though, an increase in TSC in roots was observed under waterlogging treatments.

\subsubsection{Non-reducing sugars}

Twelve days $\mathrm{W}$ and $\mathrm{S}$ treatment resulted in $30-40 \%$ and 13-19\% decline in non-reducing sugar content 1 DAR from treatment. Decline was 9-10\% 4 DAR from 12 days $W$ treatment and 6-10\% 8 DAR from 12 days S treatment. An increase of 2-7\% was also observed 4 DAR from 12 days $S$ treatment in 20 day old plant roots (Table 3 ). Forty day old plants recorded a $17-28 \%$ decline 1 DAR from 12 days
$S$ treatment. Twelve days $S$ treatment resulted in $4-7 \%$ and $8-13 \%$ decline in non-reducing sugar content 4 and 8 DAR from treatment. No plant survived 4 DAR from 12 days combined treatment, 8 DAR from 12 days waterlogging and 1 and 8 DAR from 12 days combined treatment in 20 day old pigeonpea plants and 4 DAR from 12 days and 1 and 8 DAR from 12 days waterlogging and waterlogging+salinity treatment in 40 day old pigeonpea plants. ICPH 2431 performed best among all genotypes with minimum decline in non reducing sugar content. Sairam et al. (2009a) reported that level of nonreducing sugars declined under waterlogging and reached a lowest value on the $8^{\text {th }}$ days of treatment in

Table 3: Effect of waterlogging, salinity and their combination (12 days) on non reducing sugar content (mg g ${ }^{-1}$ dry weight) in pigeonpea roots

\begin{tabular}{|c|c|c|c|c|c|c|c|c|c|c|c|c|c|}
\hline \multirow[t]{3}{*}{ Genotype } & \multicolumn{10}{|c|}{20 DAS } & \multirow{2}{*}{\multicolumn{3}{|c|}{$\begin{array}{c}40 \text { DAS } \\
12 \text { day }^{*}(1 \text { day })^{* *}\end{array}$}} \\
\hline & \multicolumn{4}{|c|}{12 day $^{*}\left(1\right.$ day) ${ }^{* *}$} & \multicolumn{4}{|c|}{12 day $^{*}\left(4\right.$ day) ${ }^{* *}$} & \multicolumn{2}{|c|}{12 day $^{*}\left(8\right.$ day) ${ }^{* *}$} & & & \\
\hline & C & W & $\mathrm{S}$ & Mean\# & $\mathrm{C}$ & W & $S$ & Mean & $\mathrm{S}$ & Mean\# & $\mathrm{C}$ & $S$ & Mean $^{\#}$ \\
\hline ICPH 2431 & 20 & 14 & 17.5 & 17.2 & 20.4 & 18.6 & 21.8 & 20.3 & 19.2 & 19.8 & 20.6 & 17 & 18.9 \\
\hline UPAS 120 & 19.8 & 11.8 & 16.1 & 15.9 & 19.9 & 17.9 & 20.3 & 19.4 & 18 & 19 & 20.2 & 15 & 17.4 \\
\hline HO9 33 & 20 & 12.5 & 16.5 & 16.3 & 20.1 & 18.4 & 20.9 & 19.8 & 18.3 & 19.2 & 20.2 & 15 & 2.4 \\
\hline PARAS & 20.1 & 13.6 & 17.4 & 17 & 20.2 & 18.6 & 21.4 & 20.1 & 18.9 & 19.6 & 20.4 & 17 & 3.1 \\
\hline Mean & 20 & 13 & 16.9 & & 20.1 & 18.4 & 21.1 & & 18.6 & & 20.4 & 16 & \\
\hline $\mathrm{CD}(p=0.05)$ & \multicolumn{4}{|c|}{$\mathrm{T}-0.42, \mathrm{G}-0.49, \mathrm{~T} \times \mathrm{G}-0.85$} & \multicolumn{4}{|c|}{ T-0.46, G-0.53, T×G-N.S. } & \multicolumn{2}{|c|}{ T-0.47, G- N.S., TXG- N.S. } & \multicolumn{3}{|c|}{ T-0.47, G-0.67, T×G-0.95 } \\
\hline
\end{tabular}

Table 3: Continue...

\begin{tabular}{|c|c|c|c|c|c|}
\hline \multirow[t]{3}{*}{ Genotype } & \multicolumn{5}{|c|}{40 DAS } \\
\hline & \multicolumn{3}{|c|}{12 day $^{*}\left(4\right.$ day) ${ }^{* *}$} & \multicolumn{2}{|c|}{12 day $^{*}\left(8\right.$ day) ${ }^{* *}$} \\
\hline & $\mathrm{C}$ & $\mathrm{S}$ & Mean & $\mathrm{S}$ & Mean" \\
\hline ICPH 2431 & 20.8 & 20 & 20.4 & 19.1 & 20 \\
\hline UPAS 120 & 20.1 & 18.8 & 19.5 & 17.4 & 18.8 \\
\hline HO9 33 & 20.3 & 19.1 & 19.7 & 17.7 & 19 \\
\hline PARAS & 20.5 & 19.8 & 20.2 & 18.4 & 19.5 \\
\hline Mean & 20.4 & 19.4 & & 18.2 & \\
\hline $\begin{array}{l}C D \\
(p=0.05)\end{array}$ & \multicolumn{3}{|c|}{$\begin{array}{c}\text { T-0.21, G-0.29, } \\
\text { T×G- N.S. }\end{array}$} & \multicolumn{2}{|c|}{$\begin{array}{c}\text { T-0.26, G-0.37, } \\
\text { T×G- } 0.52\end{array}$} \\
\hline
\end{tabular}

*: Duration of treatment; ${ }^{* *}$ : stage of sampling; : : mean value were calculated with the respective control values.

mung bean. However, V. luteola and T44 (relatively tolerant) retained higher content of nonreducing sugar content than PB (relatively susceptible). However Naureen and Naqvi (2010) reported that salinity stress of $200 \mathrm{mM}$ significantly increased the amount of nonreducing sugar in wheat.

\subsubsection{Reducing sugars}

Under 12 days $W$ treatment an increase of $47-60 \%$ was observed 1 DAR from treatment in 20 day old plant roots. Twelve days $S$ treatment resulted in $13-19 \%$ and $8-11 \%$ increase in reducing sugar 1 and 8 DAR from treatment in
20 day old plant roots. An increase of 8 to $11 \%$ under W (12 days) and 5-7\% under S (12 days) 4 DAR from treatment was recorded (Table 4). Maximum increase in ICPH 2431 and minimum in UPAS 120 in 20 day old plant roots was recorded. Forty day old plant roots recorded $8-16 \%, 5-7 \%$ and $2-7 \%$ increase 1, 4 and 8 DAR from 12 days $S$ treatments. No plant survived 4 DAR from 12 days combined treatment, 8 DAR from 12 days waterlogging and 1 and 8 DAR from 12 days combined treatment in 20 day old pigeonpea plants and 4 DAR from 12 days and 1 and 8 DAR from 12 days waterlogging and waterlogging+salinity treatment in 40 days old pigeonpea plants. ICPH 2431 was found best among the genotypes under all treatments in terms of reducing sugar content. Increased reducing sugar content in Vigna luteola was reported by Sairam et al. (2009a). Javed et al. (2014) investigated the effect of salinity $\left(8 \mathrm{dSm}^{-1}\right)$ on reducing sugar content in six varieties of safflower and reported increased content of reducing sugar under salt stress. Increase in reducing sugar content was more in ICPH 2431 among all the genotypes which reflects the mechanism behind the tolerance of that genotype to waterlogging and salinity stress as maintaining adequate levels of readily metabolizable sugars in hypoxic roots is one of the adaptive mechanisms to waterlogging.

\subsubsection{Sucrose synthase}

Under 12 days $W$ treatment an increase of $49-72 \%$ was observed 1 DAR from treatment in 20 days old plant roots 
Table 4: Effect of waterlogging, salinity and their combination (12 days) on reducing sugar content ( $\mathrm{mg} \mathrm{g}^{-1} \mathrm{dry}_{\text {weight}) \text { in }}$ pigeonpea roots

\begin{tabular}{|c|c|c|c|c|c|c|c|c|c|c|c|c|c|}
\hline \multirow[t]{3}{*}{ Genotype } & \multicolumn{10}{|c|}{20 DAS } & \multirow{2}{*}{\multicolumn{3}{|c|}{$\frac{40 \text { DAS }}{12 \text { day }^{*}(1 \text { day })^{* *}}$}} \\
\hline & \multicolumn{4}{|c|}{12 day $^{*}(1 \text { day })^{* *}$} & \multicolumn{4}{|c|}{12 day $^{*}\left(4\right.$ day) ${ }^{* *}$} & \multicolumn{2}{|c|}{12 day $^{*}(8 \text { day })^{* *}$} & & & \\
\hline & $\mathrm{C}$ & W & $S$ & Mean ${ }^{\#}$ & C & W & $S$ & Mean & $S$ & Mean ${ }^{\#}$ & C & $S$ & Mean" \\
\hline ICPH 2431 & 4.3 & 6.9 & 5.1 & 5.4 & 4.4 & 4.9 & 4.7 & 4.7 & 4.9 & 4.7 & 4.5 & 5.2 & 4.9 \\
\hline UPAS 120 & 3.8 & 5.6 & 4.3 & 4.6 & 3.9 & 4.2 & 4.1 & 4.1 & 4.2 & 4.1 & 4 & 4.3 & 4.2 \\
\hline HO9 33 & 3.9 & 5.9 & 4.4 & 4.7 & 4 & 4.3 & 4.2 & 4.2 & 4.3 & 4.2 & 4.2 & 4.6 & 4.4 \\
\hline PARAS & 4.0 & 6.3 & 4.7 & 5.0 & 4.2 & 4.6 & 4.5 & 4.4 & 4.6 & 4.4 & 4.3 & 4.9 & 4.6 \\
\hline Mean & 4.0 & 6.2 & 4.6 & & 4.1 & 4.5 & 4.4 & & 4.5 & & 4.3 & 4.8 & \\
\hline $\mathrm{CD}(p=0.05)$ & $T-0.46$ & G-0.5 &,$T \times G$ & N.S. & T-N.S & G-N. &,$T \times G$ & N.S. & T-N.S., & S., $T \times G-N$ & T-N.S & $\mathrm{G}-\mathrm{N}$ & T×G-N. \\
\hline
\end{tabular}

\begin{tabular}{|c|c|c|c|c|c|}
\hline \multirow[t]{3}{*}{ Genotype } & \multicolumn{5}{|c|}{40 DAS } \\
\hline & \multicolumn{3}{|c|}{$12 \operatorname{day}^{*}(4 \text { day) })^{* *}$} & \multicolumn{2}{|c|}{12 day $^{*}(8 \text { day })^{* *}$} \\
\hline & C & $\mathrm{S}$ & Mean & $S$ & Mean\# \\
\hline ICPH 2431 & 4.5 & 4.8 & 4.7 & 4.8 & 4.7 \\
\hline UPAS 120 & 4.2 & 4.4 & 4.3 & 4.3 & 4.3 \\
\hline HO9 33 & 4.2 & 4.4 & 4.3 & 4.4 & 4.3 \\
\hline PARAS & 4.4 & 4.7 & 4.6 & 4.7 & 4.6 \\
\hline Mean & 4.3 & 4.6 & & 4.6 & \\
\hline $\begin{array}{l}C D \\
(p=0.05)\end{array}$ & \multicolumn{3}{|c|}{$\begin{array}{c}\text { T-N.S., G-N.S., } \\
\text { T×G- N.S. }\end{array}$} & \multicolumn{2}{|c|}{$\begin{array}{l}\text { T-N.S., G-N.S., } \\
\text { T×G- N.S. }\end{array}$} \\
\hline
\end{tabular}

which further reduced to $11-16 \% 4$ DAR from 12 days $W$ treatment (Table 5). Twelve days $\mathrm{S}$ treatment resulted in $13-25 \%, 1-5 \%$ and $5-9 \%$ increase in sucrose synthase activity 1,4 and 8 DAR from treatment in 20 days old plant roots. Forty day old plant roots showed lower increase in sucrose synthase activity. Twelve days $\mathrm{S}$ treatment resulted in 9-21\%, $2-4 \%$ and $3-6 \%$ increase 1,4 and 8 DAR from treatment. No plant survived 4 DAR from 12 days combined treatment, 8 DAR from 12 days waterlogging and 1 and 8 DAR from 12 days combined treatment in 20 days old pigeonpea plants and 4

DAR from 12 days and 1 and 8 DAR from 12 days waterlogging and waterlogging+salinity treatment in 40 days old pigeonpea plants. ICPH 2431 was found best among the genotypes under all treatment in terms of sucrose synthase activity. Stress induces to increase the content of reducing sugar through increased activity of SS in tolerant genotype to cope up with stress (Hossain and Uddin, 2011). The results suggest that waterlogging tolerance of pigeonpea genotypes ICPH 2431 and PARAS depends on the availability of sufficient sugar reserve in the roots, activity of sucrose synthase to provide reducing sugars for glycolytic activity.

\subsubsection{Alcohol dehydrogenase}

Twelve days $\mathrm{W}$ and $\mathrm{S}$ treatments resulted in $49-61 \%$ and $16-31 \%$ increase in enzyme activity 1 DAR from treatments in 20 days old plant roots. A partial recovery was observed 4 DAR from 12 days $W$ and $S$ treatments with $19-34 \%$ and $9-14 \%$ increase in enzyme activity. A higher increase of 11 to $18 \% 8$ DAR from 12 days $S$ treatment was observed (Table 6). In 40 days old plant roots, an increase of $15-30 \%, 9-11 \%$ and $8-16 \%$ in ADH activity was observed 1,4 and 8 DAR from 12 days $S$ treatment. No plant survived 4 DAR from 12 days combined treatment, 8 DAR from 12 days waterlogging and 1 and 8 DAR from 12 days combined treatment in 20 day old pigeonpea plants and 4 DAR from 12 days and 1 and 8

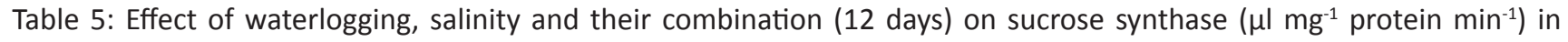
pigeonpea roots

\begin{tabular}{|c|c|c|c|c|c|c|c|c|c|c|c|c|c|}
\hline \multirow[t]{3}{*}{ Genotype } & \multicolumn{10}{|c|}{20 DAS } & \multicolumn{3}{|c|}{40 DAS } \\
\hline & \multicolumn{4}{|c|}{12 day $^{*}(1 \text { day })^{* *}$} & \multicolumn{4}{|c|}{12 day $^{*}(4 \text { day) })^{* *}$} & \multicolumn{2}{|c|}{12 day $^{*}(8 \text { day })^{* *}$} & \multicolumn{3}{|c|}{12 day $^{*}(1 \text { day })^{* *}$} \\
\hline & $\mathrm{C}$ & W & $\mathrm{S}$ & Mean\# & C & W & $S$ & Mean & $S$ & Mean $^{\#}$ & $C$ & $S$ & Mean\# \\
\hline ICPH 2431 & 1.05 & 1.81 & 1.31 & 1.39 & 1.06 & 1.23 & 1.11 & 1.13 & 1.16 & 1.11 & 1.07 & 1.3 & 1.18 \\
\hline UPAS 120 & 1.01 & 1.5 & 1.14 & 1.22 & 1.02 & 1.13 & 1.03 & 1.06 & 1.07 & 1.05 & 1.03 & 1.1 & 1.08 \\
\hline HO9 33 & 1.02 & 1.62 & 1.16 & 1.27 & 1.03 & 1.15 & 1.05 & 1.08 & 1.09 & 1.06 & 1.04 & 1.2 & 1.09 \\
\hline PARAS & 1.04 & 1.78 & 1.28 & 1.37 & 1.04 & 1.2 & 1.08 & 1.11 & 1.12 & 1.08 & 1.05 & 1.3 & 1.15 \\
\hline Mean & 1.03 & 1.68 & 1.22 & & 1.04 & 1.18 & 1.07 & & 1.11 & & 1.05 & 1.2 & \\
\hline $\operatorname{CD}(p=0.05)$ & \multicolumn{4}{|c|}{ T-0.05, G-0.05, T×G- 0.09} & \multicolumn{4}{|c|}{ T-0.06, G-N.S., T×G- N.S. } & T-0.06, & ., T×G- N.S. & \multicolumn{3}{|c|}{ T-0.07, G-N.S., T×G- N.S } \\
\hline
\end{tabular}




\begin{tabular}{|c|c|c|c|c|c|}
\hline \multicolumn{6}{|c|}{ Table 5: Continue... } \\
\hline \multirow[t]{3}{*}{ Genotype } & \multicolumn{5}{|c|}{40 DAS } \\
\hline & \multicolumn{3}{|c|}{12 day $^{*}\left(4\right.$ day) ${ }^{* *}$} & \multicolumn{2}{|c|}{12 day $^{*}\left(8\right.$ day) ${ }^{* *}$} \\
\hline & $\mathrm{C}$ & $\mathrm{S}$ & Mean & $\mathrm{S}$ & Mean" \\
\hline ICPH 2431 & 1.08 & 1.12 & 1.11 & 1.15 & 1.12 \\
\hline UPAS 120 & 1.03 & 1.05 & 1.04 & 1.06 & 1.04 \\
\hline HO9 33 & 1.05 & 1.07 & 1.05 & 1.08 & 1.07 \\
\hline PARAS & 1.06 & 1.09 & 1.08 & 1.12 & 1.09 \\
\hline Mean & 1.06 & 1.08 & & 1.1 & \\
\hline $\begin{array}{l}\text { CD } \\
(p=0.05)\end{array}$ & \multicolumn{3}{|c|}{$\begin{array}{c}\text { T- N.S., G- N.S., } \\
\text { T×G- N.S. }\end{array}$} & \multicolumn{2}{|c|}{$\begin{array}{c}\text { T-0.04, G-N.S., } \\
\text { T×G- N.S. }\end{array}$} \\
\hline
\end{tabular}

DAR from 12 days waterlogging and waterlogging+salinity treatment in 40 days old pigeonpea plants. Maximum increase was observed in ICPH 2431 and minimum in UPAS 120. Wang et al. (2009) reported increase in the activity of ADH in the roots of Kentucky bluegrass under three days of waterlogging conditions. Similar results were noticed by Chen and Quallis (2003) in roots of perennial pepper weed. Akhtar et al. (1998) measured ADH activity in wheat roots and reported comparatively higher activity under saline-hypoxic compared to salinity and hypoxia alone. These results suggest that waterlogging tolerance of pigeonpea genotypes ICPH 2431 and PARAS depends on the availability of sufficient ADH for the recycling of $\mathrm{NADH}$, essential for the continuation of glycolysis, the major source of energy under hypoxia.

Table 6: Effect of waterlogging, salinity and their combination on ADH activity $\left(\mu\right.$ mol NADH $\mathrm{mg}^{-1}$ protein min ${ }^{-1}$ ) in pigeonpea roots

\begin{tabular}{|c|c|c|c|c|c|c|c|c|c|c|c|c|c|}
\hline \multirow[t]{3}{*}{ Genotype } & \multicolumn{10}{|c|}{20 DAS } & \multicolumn{3}{|c|}{40 DAS } \\
\hline & \multicolumn{4}{|c|}{12 day $^{*}\left(1\right.$ day) ${ }^{* *}$} & \multicolumn{4}{|c|}{12 day* $^{*} 4$ day) ${ }^{* *}$} & \multicolumn{2}{|c|}{12 day* $^{*} 8$ day) ${ }^{* *}$} & \multicolumn{3}{|c|}{12 day $^{*}\left(1\right.$ day) ${ }^{* *}$} \\
\hline & $\mathrm{C}$ & W & S & Mean" & C & W & $\mathrm{S}$ & Mean & S & Mean" & $\mathrm{C}$ & $\mathrm{S}$ & Mean" \\
\hline ICPH 2431 & 0.55 & 0.91 & 0.72 & 0.73 & 0.55 & 0.74 & 0.63 & 0.64 & 0.65 & 0.6 & 0.55 & 0.7 & 0.64 \\
\hline UPAS 120 & 0.54 & 0.8 & 0.63 & 0.65 & 0.54 & 0.64 & 0.59 & 0.59 & 0.6 & 0.57 & 0.54 & 0.6 & 0.59 \\
\hline HO9 33 & 0.54 & 0.81 & 0.65 & 0.67 & 0.54 & 0.67 & 0.6 & 0.6 & 0.62 & 0.58 & 0.55 & 0.6 & 0.6 \\
\hline PARAS & 0.54 & 0.86 & 0.69 & 0.7 & 0.55 & 0.72 & 0.61 & 0.63 & 0.64 & 0.59 & 0.55 & 0.7 & 0.62 \\
\hline Mean & 0.541 & 0.85 & 0.67 & & 0.55 & 0.69 & 0.61 & & 0.63 & & 0.55 & 0.7 & \\
\hline $\operatorname{CD}(p=0.05)$ & \multicolumn{4}{|c|}{ T-0.02, G- 0.03, TXG-0.05 } & \multicolumn{4}{|c|}{ T-0.02, G-0.02, TXG-0.03 } & $\mathrm{T}-0.02$, & 2, TXG-N.S. & \multicolumn{3}{|c|}{ T-0.03, G-0.04, TXG- N.S. } \\
\hline
\end{tabular}

Table 6: Continue...

\begin{tabular}{|c|c|c|c|c|c|}
\hline \multirow[t]{3}{*}{ Genotype } & \multicolumn{5}{|c|}{40 DAS } \\
\hline & \multicolumn{3}{|c|}{12 day $^{*}(4 \text { day })^{* *}$} & \multicolumn{2}{|c|}{12 day $^{*}\left(8\right.$ day) ${ }^{* *}$} \\
\hline & $\mathrm{C}$ & $\mathrm{S}$ & Mean & $\mathrm{S}$ & Mean $^{\#}$ \\
\hline ICPH 2431 & 0.56 & 0.62 & 0.59 & 0.65 & 0.61 \\
\hline UPAS 120 & 0.55 & 0.6 & 0.58 & 0.59 & 0.57 \\
\hline HO9 33 & 0.55 & 0.61 & 0.58 & 0.61 & 0.58 \\
\hline PARAS & 0.56 & 0.62 & 0.59 & 0.63 & 0.6 \\
\hline Mean & 0.55 & 0.62 & & 0.62 & \\
\hline $\mathrm{CD}$ & \multirow{2}{*}{\multicolumn{3}{|c|}{$\begin{array}{c}\text { T-0.02, G-N.S., } \\
\text { TXG- N.S. }\end{array}$}} & \multirow{2}{*}{\multicolumn{2}{|c|}{$\begin{array}{c}\text { T-0.02, G-N.S., } \\
\text { TXG- N.S. }\end{array}$}} \\
\hline$(p=0.05)$ & & & & & \\
\hline
\end{tabular}

": Duration of treatment; ${ }^{* *}$ : stage of sampling; \#: Mean value were calculated with the respective control values

\subsubsection{Aerenchyma formation}

Aerenchyma is a special tissue which consists of continuous gas filled channels or much enlarged gas spaces. Aerenchyma formation was observed under $W$ and $W+S$ treatments (Figure 1, 2). The aerenchyma formation was less in sensitive genotypes as compared to tolerant genotypes. Hossain and Uddin (2011) in wheat and De-Souza et al. (2009) in maize also noticed formation of aerenchyma in root tissue of tolerant variety of wheat in response to anoxia. In control plant there was no aerenchyma formation. Alone salinity treatment also
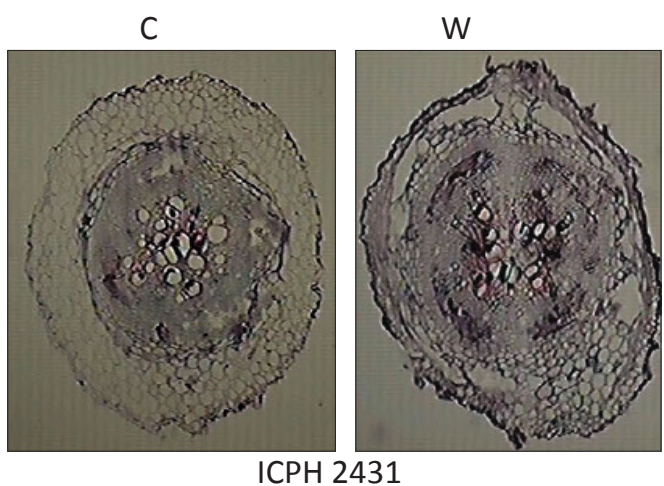

$\mathrm{W}+\mathrm{S}$
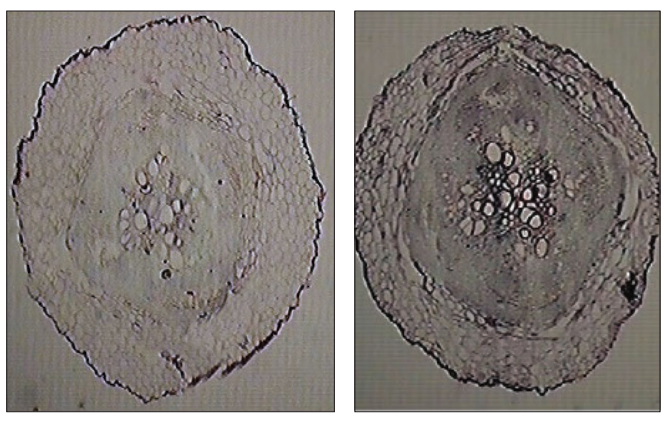

No Survival

UPAS 120

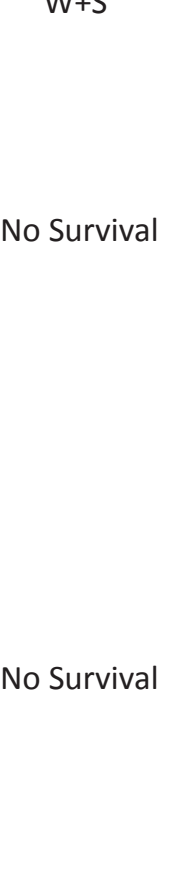

Continue... 

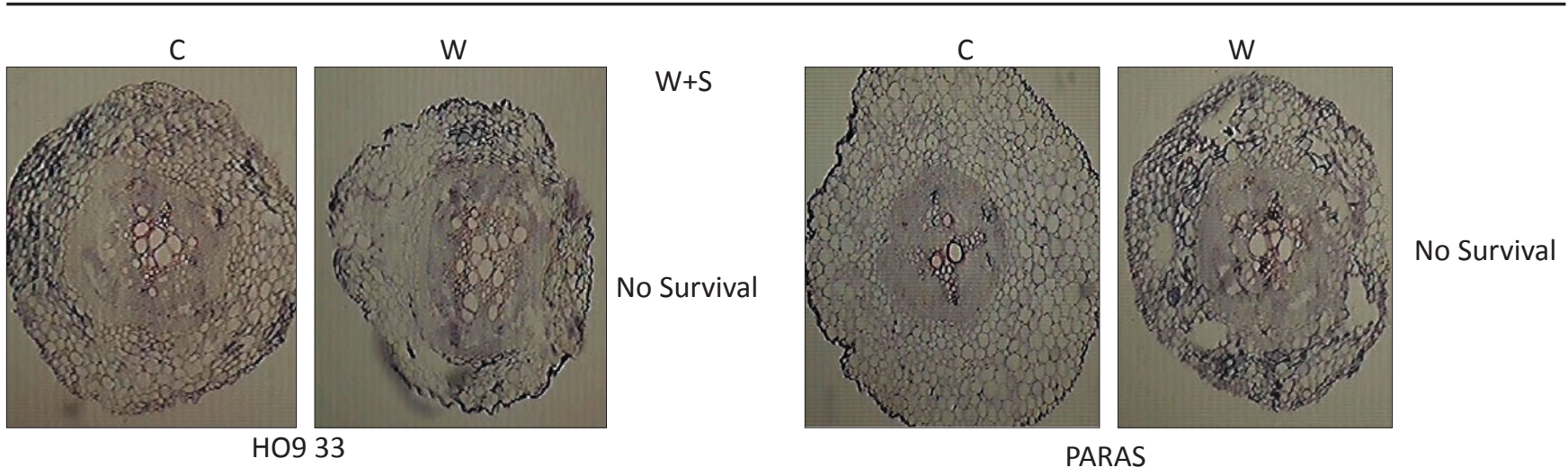

Figure 1: Aerenchyma formation in roots of 20 days old pigeonpea genotypes 1 DAR from 12 days $W$ and $W+S$ treatments

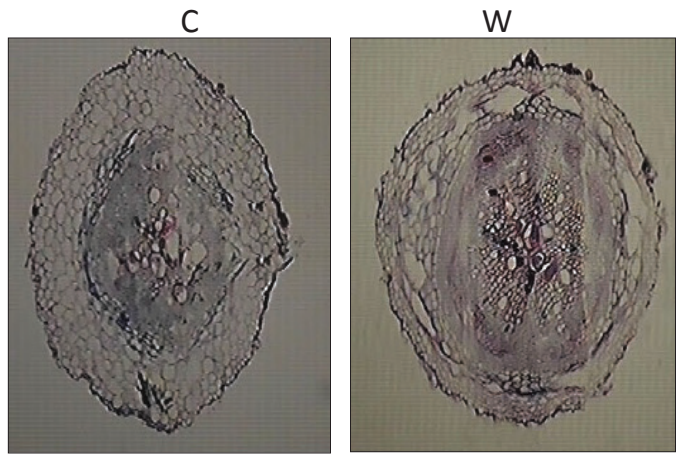

ICPH 2431

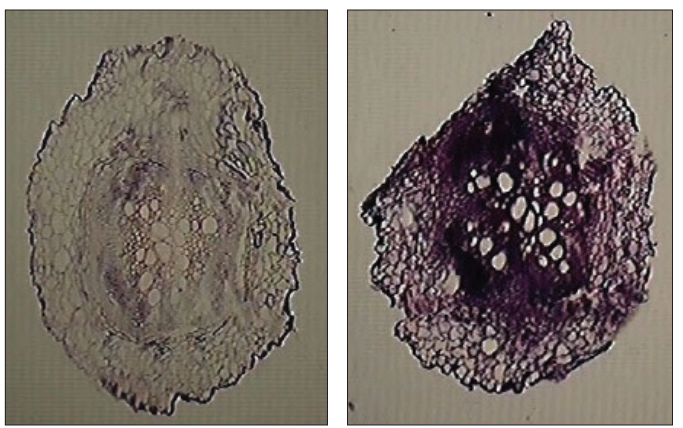

HO9-33
W+S

No Survival
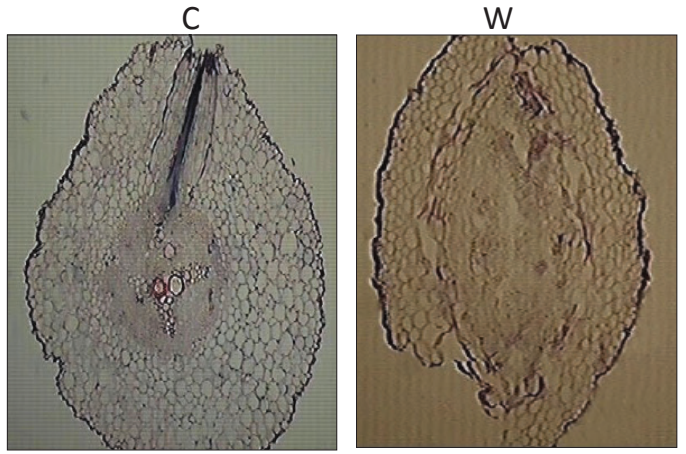

$\mathrm{W}+\mathrm{S}$

UPAS 120
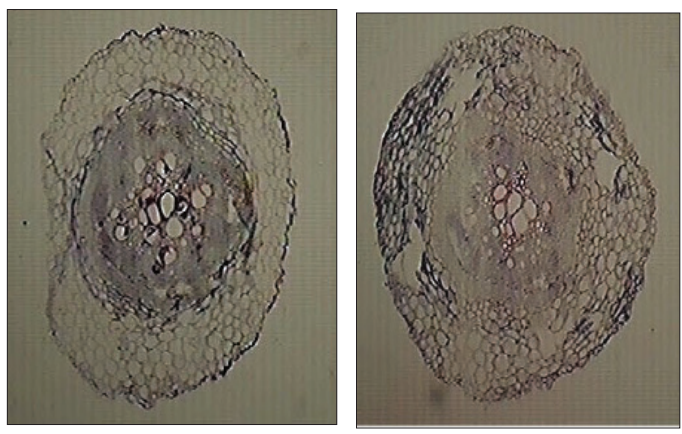

PARAS

No Survival

Figure 2: Aerenchyma formation in roots of 20 days old pigeonpea genotypes 4 DAR from 12 days $W$ and $W+S$ treatments

resulted in no aerenchyma formation. It may concluded from this study that combined stress of waterlogging and salinity is more deleterious compared to these stresses alone and aerenchyma formation is one of the strategy which plants opt to cope up with waterlogging and combined stress. More aerenchyma formation in ICPH 2431 and PARAS represent tolerant behavior of these genotypes towards waterlogging and combined stress. It is also concluded from the study that stress become more deleterious when given for long time and at later vegetative stages.

\section{Conclusion}

Waterlogging and salinity in combination are more deleterious to plants of pigeonpea as compared to these stresses alone. All the three stresses are more deleterious when given at later stages of growth. Tolerant pigeonpea genotypes had a better carbohydrate metabolism and more aerenchyma formation to cope with waterlogging and salinity and this represent the tolerant behavior of these genotypes towards waterlogging and salinity stress.

\section{Acknowledgement}

Authors are thankful to Head, Department of Botany and Plant Physiology, CCS HAU, Hisar, Haryana for providing necessary facilities for successful conduct of this work.

\section{References}

Akhtar, J., Gorham, J., Qureshi, R.H., Aslam, M., 1998. Does tolerance of wheat to salinity and hypoxia correlate with root dehydrogenase activities or aerenchyma formation? Plant and Soil 201(2), 275-284.

Akhtar, I., Nazir, N., 2013. Effect of waterlogging and drought 
stress in plants. International Journal of Water Resources and Environmental Sciences 2(2), 34-40.

Aksoy, M., Dinler, B.S., 2012. Changes in physiological parameters and some antioxidant enzymes activities of soybean (Glycine max L. M err.) leaves under cadmium and salt stress. Journal of Stress Physiology and Biochemistry 8(4), 179-190.

Amirjani, M.R., 2010. Effect of salinity stress on growth, mineral composition, proline content, antioxidant enzymes of soybean. American Journal of Plant Physiology 5, 350-360.

Ashraf, M.A., 2012. Waterlogging stress in plants: a review. African Journal of Agricultural Research 7(13), 19761981.

Bajpai, S., Chandra, R., 2015. Effect of waterlogging stress on growth characterstics and sod gene expression in sugarcane. International Journal of Scientific and Research Publication 5(1), 1-8.

Bansal, R., Srivastava, J.P., 2012. Antioxidative defense system in pigeonpea roots under waterlogging stress. Acta Physiologiae Plantarum 34, 515-522.

Basiri, H.K., Sepheri, A., Sadegi, M., 2013. Effect of salinity on germibnation of Safflower seed (Carthamus tinctorius L. cv. Poymar). Technical Journal of Engineering and Applied Sciences 3(11), 934-937

Barrett-Lennard, E.G., 2003. The interaction between waterlogging and salinity in higher plants, causes, consequences and implications. Plant and Soil 253, 35-54.

Celik, A., Atak, C., 2012. The effect of salt stress on antioxidative enzymes and proline content of two Turkish tobacco varieties. Turkish Journal of Biology 36, 339-356.

Chen, H., Quallis, R.G., 2003. Anaerobic metabolism in roots of the seedlings of invasive exotic Lepidium latifolium. Environmental and Experimental Botany 50, 29-40.

Choudhary, A.K., Sultana, R., Pratap, A., Nadarajan, N., Jha, U.D., 2011. Breeding for abiotic stresses in pigeonpea. Journal Food Legumes 24(3), 165-174.

CSSRI, 2016. Extent and distribution of salt affected soils in India, Central Soil Salinity Research Institute Karnal, Haryana, India.

De-Souza, T.C., De-Castro, E.M., Pereira, F.J., Parentoni, S.N., Magalhaes, P.C., 2009. Morpho-anatomical characterization of root in recurrent selection cycles for flood tolerance of maize (Zea mays L.). Plant Soil and Environment 55(11), 504-510.

Drew, M.C., Gunther, J., Lauchli, A., 1988. The combined effects of salinity and root anoxia on growth and net $\mathrm{Na}^{+}$and $\mathrm{K}^{+}$accumulation in Zea mays grown in solution culture. Annals of Botany 61, 41-53.

Horchani, F., Hajri, R., Khayati, H., Aschi-Smitis, S., 2010. Physiological responses of tomato plants to the combined effect of root hypoxia and $\mathrm{NaCl}$-salinity. Journal of Phytology 2, 36-46.

Hossain, M.A., Uddin, S.N., 2011. Mechanisms of waterlogging tolerance in wheat, Morphological and metabolic adaptations under hypoxia or anoxia. Australian Journal of Crop Science 5(9), 1094-1101.

Javed, S., Bukhari, S.A., Ashraf, M.Y., Mahmood, S., Iftikhar, T., 2014. effect of salinity on growth, biochemical parameters and fatty acid composition in safflower (Carthamus tinctorius L.). Pakistan Journal of Botany 46(4), 1153-1158.

Johansen, D.A., 1940. Plant Microtechnique. $1^{\text {st }}($ Edn). McGraw-Hill Book Company Inc., New York, London, 523.

Kulkarni, S.S., Chavan, P.D., 2013. Influence of waterlogging on carbohydrate metabolism in Ragi and Rice roots. Journal of Stress Physiology and Biochemistry 9(2), 199-205.

Miller, G.L., 1959. Use of dinitrosalicylic acid reagent for determination of reducing sugar. Analytical Chemistry 31(3), 426-428.

Naureen, G., Naqvi, F.N., 2010. Salt tolerance classification in wheat genotypes using reducing sugar accumulation and growth characteristics. Emirates Journal of Food and Agriculture 22(4), 308-317.

Sairam, R.K., Kumutha, D., Chinnusamy, V., Meena, R,C., 2009a. Waterlogging induced increase in sugar mobilization, fermentation, and related gene expression in the roots of mung bean (Vigna radiata). Journal of Plant Physiology 166, 602-616.

Sairam, R.K., Kumutha, D., Ezhilmathi, K., Chinnusamy, V., Meena, R.C., 2009b. Waterlogging induced oxidative stress and antioxidant enzyme activities in pigeonpea. Biologia Plantarum 53(3), 493-504.

Sass, J.E., 1964. Botanical microtechnique. Oxford, IBH Publishing Company, New Delhi.

Wang, Z., Gerstein, M., Snyder, M., 2009. RNA-Seq: a revolutionary tool for transcriptomics. Nature Reviews Genetics 10(1), 57-63.

Yemm, E.W., Willis, A.J., 1954. The Estimation of carbohydrate in the plant extract by anthrone reagent. Journal of Biochemistry 57, 508-514.

Zeng, F., Shabala, L., Zhou, M., Zhang, G., Shabala, S., 2013. Barley responses to combined waterlogging and salinity stress, separating effects of oxygen deprivation and elemental toxicity. Frontier in Plant Science 4, 1-13. 